\title{
Publisher Correction: Quantitative image analysis of microbial communities with BiofilmQ
}

Raimo Hartmann, Hannah Jeckel, Eric Jelli (D), Praveen K. Singh (D), Sanika Vaidya, Miriam Bayer, Daniel K. H. Rode, Lucia Vidakovic, Francisco Díaz-Pascual, Jiunn C. N. Fong, Anna Dragoš, Olga Lamprecht (D), Janne G. Thöming (D), Niklas Netter, Susanne Häussler (D), Carey D. Nadell (D), Victor Sourjik (D), Ákos T. Kovács (D), Fitnat H. Yildiz and Knut Drescher (i)

Correction to: Nature Microbiology https://doi.org/10.1038/s41564-020-00817-4, published online 4 January 2021.

In the version of this Brief Communication originally published, in Fig. 1e, the cytometry data were mistakenly omitted from all three graphs. This error has now been corrected and the updated figure is available online.

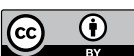

Open Access This article is licensed under a Creative Commons Attribution 4.0 International License, which permits use, sharing, adaptation, distribution and reproduction in any medium or format, as long as you give appropriate credit to the original author(s) and the source, provide a link to the Creative Commons license, and indicate if changes were made. The images or other third party material in this article are included in the article's Creative Commons license, unless indicated otherwise in a credit line to the material. If material is not included in the article's Creative Commons license and your intended use is not permitted by statutory regulation or exceeds the permitted use, you will need to obtain permission directly from the copyright holder. To view a copy of this license, visit http://creativecommons.org/ licenses/by/4.0\%.

Published online: 8 January 2021

https://doi.org/10.1038/s41564-021-00863-6

() The Author(s) 2021 